\title{
Comparative Study of Attitude of Adolescents Studying in Junior Colleges of Rural and Urban Areas of Vijayapura towards Social Aspects of Life
}

\author{
Sadashiva Basavantappa Ukkali ${ }^{1}$, Nagamani Kulkarni², \\ A.N. Thobbi ${ }^{3}$, Ayesha Siddiqua ${ }^{4}$, Shruthi Reddy ${ }^{5}$ \\ 1, 2, 3, 4, 5 Department of Paediatrics, Al-Ameen Medical College, Bijapur, Karnataka, India.
}

\section{ABSTRACT}

\section{BACKGROUND}

Adolescent period is that part of exciting period of life which marks the transition from being a dependent kid to an independent and responsible adult. It is recognised as a fascinating period that poses specific challenges and has a great impact on the physical, social and emotional behaviour in the family and society.

\section{METHODS}

A comparative cross-sectional survey of a total of 1000 adolescents, 16 - 18 years of age -250 each from 4 PU colleges ( 2 urban +2 rural) were interviewed using a pretested questionnaire. Based on responses, their attitude towards social aspects of life were assessed, analysed and compared.

\section{RESULTS}

There were significant differences in attitude of adolescents residing in urban areas on various social aspects of life as compared to the adolescents residing in rural areas. Significant differences were observed in personality development traits like selfesteem and self-concept, shrewdness, tender mindedness, internal restraint and individual capacities. Risk taking behaviour was more common in urban adolescents and academic underachievement was more common in rural adolescents. There were no significant differences between the two groups with respect to home / college environment, safety at home / college, relationships with parents, siblings and friends, depression and social ideation.

\section{CONCLUSIONS}

We observed that rural and urban adolescents differed significantly in their attitude towards development of personality traits. Rural adolescents were academically underachievers because of poor facilities, less opportunities and lack of motivation. Urban adolescents exhibited high risk-taking behaviour compared to rural adolescents because of high peer-pressure, curiosity and more exposure to mass media.

\section{KEY WORDS}

Adolescent, Attitude, Rural, Urban, Social
Corresponding Author:

Dr. Sadashiva Basavantappa Ukkali,

Associate Professor,

Department of Paediatrics,

Al-Ameen Medical College, Bijapur,

Karnataka, India.

E-mail: saduukkali@yahoo.co.in

DOI: $10.14260 /$ jemds/2021/271

How to Cite This Article:

Ukkali SB, Kulkarni N, Thobbi AN, et al. Comparative study of attitude of adolescents studying in junior colleges of rural and urban areas of Vijayapura towards social aspects of life. J Evolution Med Dent Sci 2021;10(18):1280-1285, DOI: 10.14260/jemds/2021/271

Submission 05-11-2020,

Peer Review 24-02-2021,

Acceptance 05-03-2021,

Published 03-05-2021.

Copyright (C) 2021 Sadashiva Basavantappa Ukkali et al. This is an open access article distributed under Creative Commons Attribution License [Attribution 4.0 International (CC BY 4.0)] 


\section{BACKGROUND}

Adolescent period is that part of the fascinating period of life which marks the transition from being a dependent kid to an independent and responsible adult. Adolescents, their parents and health care givers face a challenging task during adolescence. ${ }^{1}$ Rights and medical needs of adolescent's conflict with the rights and wishes of their parents during this period. Significant changes occur for the individual socially, although most adolescents today remain financially and physically dependent on their parents. At school, more emphasis is placed on self-motivation and self-discipline. Peer relationships gain increasing importance, heterosexual interest and activities increase and majority of adolescents experience some form of sexual activity. ${ }^{2}$

Predominant changes occur during adolescent period virtually in every facet of life, changes in physical structure, physiological and endocrine changes, changes in patterns of thinking, in attitude and ideas, relationships, moral standards and abilities regarding future careers with confidence.

Several complex factors contribute to healthy and sound development of adolescents viz, environment where they reside, economic background, quality of relationship they share with friends / peers, parents and community and opportunities available.

So, knowing the attitude of adolescents at this stage is more realistic. As adolescent's physical and social development is dependent on the socio-economic status, local culture, that is the reason this study has been undertaken for comparing the attitude of adolescents of rural and urban areas with respect to social aspects of life.

Urban adolescents are drowned by flood of opportunities and the rural youths are toiling due to drought of opportunities. This may be the reason for harbinger of psychiatric illnesses. ${ }^{3}$ Thus, present work is undertaken to understand the attitude of adolescents studying in two contrasting set-ups (junior colleges of rural and urban areas) of Vijayapura towards social aspects of life and compare the same.

\section{Objectives}

- To know the attitude of adolescent studying in junior colleges of rural and urban areas of Vijayapura towards social aspects of life.

- To compare the attitude of adolescents studying in junior colleges of rural and urban areas of Vijayapura towards social aspects of life.

\section{METHODS}

A comparative cross-sectional survey was conducted from June 2019 to January 2020 in 2 rural and 2 urban junior colleges of Vijayapura in order to know and compare the attitude of adolescents towards social aspects of life.

\section{Inclusion Criteria}

- Adolescents between 16 - 18 years of age.

- Studying in $11^{\text {th }}$ and $12^{\text {th }}$. (PUC $1^{\text {st }}$ and $2^{\text {nd }}$ year).

\section{Exclusion Criteria}

- Students less than 16 and more than 18 years of age.

- Those who are unwilling for the study.

- Those who are staying in hostel.

\section{Study Population / Sample Size}

Four junior colleges ( 2 urban and 2 rural) were chosen for the study. 250 adolescents per college (age group $16-18$ years), accounting for 500 each from rural and urban colleges of Vijayapura were selected by stratified random sampling and interviewed using a pre-tested questionnaire. Depending on responses, their attitude with respect to social aspect of life was studied and compared.

\section{The junior colleges selected were}

Rural

- $\quad$ B.S. Patil Junior College, Managoli.

- Government Pre-University College, Honnutagi.

\section{Urban}

- $\quad$ Pandrangarao Desai Jubilee College, Vijayapura.

- $\quad$ SECAB Pre University College, Vijayapura.

The above colleges were selected by stratified random sampling. The purpose and essence of the study were explained to the principals and authorities of the respective colleges and the permission was obtained. Study was conducted during college working hours. All the students in the class present on the day of interview were enrolled for the study. The objectives of the study were explained to the students and their consent was obtained.

Pretested, self-designed questionnaires were distributed to all the students enrolled for the study and present on that day. The questionnaire included details of adolescents, socioeconomic status, adolescent's attitude towards college / home environment, peer group, friends, society, their lifestyles, risky behaviours etc. The contents of the questionnaire were translated and explained in local language also. After briefing about the purpose of study, students were told to write their responses in the questionnaire at a time so that all queries could be attended to. Students were informed that participation was optional, and information was anonymous.

Students were asked to answer all the questions from the questionnaire, though they were not forced and were given an option to skip a particular question if they wished to do so. Discussion among the students was discouraged. We avoided teacher's supervision to make the students feel free and relaxed in order to get unbiased responses from them. Confidentiality was maintained throughout the study.

\section{Statistical Analysis}

The absolute values and proportions for each variable in rural and urban colleges were compared. A chi-square test was used to compare the proportions wherever applicable in order to prove the difference is statistically significant. A ' $\mathrm{P}$ ' value of < 0.05 was taken as statistically significant. 


\begin{tabular}{|c|c|c|c|c|c|}
\hline Parameter & Criteria & Rural (\%) & Urban (\%) & $\mathbf{x}^{2}$ & P-Value \\
\hline \multirow{3}{*}{ Self esteem } & Very high & $144(28.8)$ & $356(71.2)$ & 179.6 & $<0.001$ \\
\hline & Normal & $310(62)$ & $86(17.2)$ & 209.7 & $<0.001$ \\
\hline & Low & $46(9.2)$ & $58(11.6)$ & 1.545 & $>0.10$ \\
\hline \multirow{6}{*}{ The character which he / she dislikes } & Lying & $67(13.4)$ & $65(13)$ & 0.034 & $>0.50$ \\
\hline & Anger & $114(22.8)$ & $101(20.2)$ & 1.001 & $>0.10$ \\
\hline & Laziness & $198(39.6)$ & $196(39.2)$ & 0.016 & $>0.50$ \\
\hline & Cruelty & $52(10.4)$ & $37(7.4)$ & 2.774 & $>0.05$ \\
\hline & Sleepiness & $51(10.2)$ & $82(16.4)$ & 8.333 & $<0.005$ \\
\hline & Others & $18(3.6)$ & $19(3.8)$ & 0.028 & $>0.10$ \\
\hline \multirow{6}{*}{$\mathrm{He} /$ she is best at } & Drawing & $85(17)$ & $65(13)$ & 3.136 & $>0.05$ \\
\hline & Studies & $129(25.8)$ & $220(44)$ & 36.447 & $<0.001$ \\
\hline & Dancing & $68(13.6)$ & $68(13.6)$ & - & - \\
\hline & Singing & $66(13.2)$ & $66(13.2)$ & - & - \\
\hline & Sports & $90(18)$ & $61(12.2)$ & 6.559 & $<0.02$ \\
\hline & Others & $62(12.4)$ & $20(4)$ & 19.181 & $<0.01$ \\
\hline \multirow{3}{*}{ Home environment } & Very good & $461(92.2)$ & $459(91.8)$ & 0.054 & $>0.50$ \\
\hline & Good & $31(6.2)$ & $28(5.6)$ & 0.620 & $>0.10$ \\
\hline & Bad & $8(1.6)$ & $13(2.6)$ & 1.215 & $>0.10$ \\
\hline \multirow{5}{*}{ In case of problems, he / she will approach } & Father & $37(7.4)$ & $70(14)$ & 11.396 & $<0.001$ \\
\hline & Mother & $310(62)$ & $262(52.4)$ & 9.410 & $<0.005$ \\
\hline & Siblings & $31(6.2)$ & $39(7.8)$ & 0.982 & $>0.10$ \\
\hline & Friend & $117(23.4)$ & $126(25.2)$ & 0.440 & $>0.50$ \\
\hline & Relative & $5(1)$ & $3(0.6)$ & 0.504 & $>0.10$ \\
\hline \multirow{3}{*}{ Impression towards parents / siblings } & Great & $416(83.2)$ & $430(86)$ & 2.544 & $>0.10$ \\
\hline & Good & $76(15.2)$ & $54(10.8)$ & 4.279 & $<0.05$ \\
\hline & Not good & $8(1.6)$ & $16(3.2)$ & 2.732 & $>0.05$ \\
\hline & Too much & $362(72.4)$ & $420(84)$ & 19.731 & $<0.001$ \\
\hline People's expectations from adolescents & To certain extent & $82(16.4)$ & $64(12.8)$ & 2.598 & $>0.10$ \\
\hline & Not at all & $56(11.2)$ & $16(3.2)$ & 23.94 & $<0.001$ \\
\hline & Comfortable & $442(88.4)$ & $429(85.2)$ & & \\
\hline Comfort at home & Uncomfortable & $58(11.6)$ & $71(14.2)$ & 1.50 & $>0.10$ \\
\hline & Too many members & $22(37.93)$ & $9(12.67)$ & 11.163 & $<0.001$ \\
\hline Reason for being uncomfortable at home & Parental / sibling quarrels & $31(53.44)$ & $19(26.67)$ & 9.573 & $<0.005$ \\
\hline & Parental criticism & $5(8.62)$ & $43(60.56)$ & 36.869 & $<0.001$ \\
\hline & Stop talking to parents & $161(32.2)$ & $133(26.6)$ & 3.776 & $>0.05$ \\
\hline Reaction when upset with parents & Cry / sleep off & $233(46.6)$ & $205(41)$ & 3.184 & $>0.05$ \\
\hline & Feel depressed & $106(21.2)$ & $162(32.4)$ & 15.985 & $<0.001$ \\
\hline & Watching TV / movies & $189(37.8)$ & $238(47.6)$ & 9.812 & $<0.005$ \\
\hline Entertainment & Chatting with friends & $197(39.4)$ & $204(40.8)$ & 0.203 & $>0.10$ \\
\hline & Playing games & $114(22.8)$ & $58(11.6)$ & 22.019 & $<0.001$ \\
\hline $\begin{array}{l}\text { Having a best friend with whom he / she can } \\
\text { speak to about anything }\end{array}$ & & $338(67.6)$ & $349(69.8)$ & 0.562 & $>0.10$ \\
\hline & Father & $35(7)$ & $101(20.2)$ & 37.070 & $<0.001$ \\
\hline & Mother & $177(35.4)$ & $194(38.8)$ & 1.237 & $>0.10$ \\
\hline & Friend & $104(20.8)$ & $118(23.6)$ & 1.133 & $>0.10$ \\
\hline The person with whom he / she confides when in & Sibling & $53(10.6)$ & $21(4.2)$ & 14.942 & $<0.001$ \\
\hline & Teacher & $48(9.6)$ & $25(5)$ & 7.816 & $<0.01$ \\
\hline & God & $72(14.4)$ & $33(6.6)$ & 16.184 & $<0.001$ \\
\hline & Relative & $11(2.2)$ & $8(1.6)$ & 0.482 & $>0.10$ \\
\hline & Positive & $445(89)$ & $421(84.2)$ & 1.33 & $>0.10$ \\
\hline Influence of friends & Negative & $55(11)$ & $79(15.8)$ & 1.33 & $>0.10$ \\
\hline Getting enough time for routine & & $403(80.6)$ & $359(71.8)$ & 10.67 & $<0.005$ \\
\hline & Planned & $192(38.4)$ & $346(69.2)$ & & \\
\hline Routine & Not planned & $308(61.6)$ & $154(30.8)$ & 95.41 & $<0.001$ \\
\hline & Cool and joyful & $429(85.8)$ & $474(94.8)$ & & \\
\hline Present life & Boring & $71(14.2)$ & $26(5.2)$ & 23.11 & $<0.001$ \\
\hline & Happy person & 422 & 428 & 0.2823 & \\
\hline Feeling about self & Sad & 57 & 27 & 11.696 & $\begin{array}{c}>0.50 \\
<0001<0.005\end{array}$ \\
\hline & Both(changing) & 21 & 45 & 9.343 & $<0.001<0.005$ \\
\hline Understands about bodily changes / body image & & $449(89.8)$ & $484(96.8)$ & 19.595 & $<0.001$ \\
\hline & Self & $25(5)$ & $41(8.2)$ & 4.152 & $<0.05$ \\
\hline Alcohol abuse & Friends & $25(5)$ & $60(12)$ & 15.749 & $<0.001$ \\
\hline Drug abuse & - & - & - & - & - \\
\hline & $\begin{array}{l}\text { Having girlfriend / boyfriend } \\
\text { Free socialization with opposite }\end{array}$ & $24(4.8)$ & $78(15.6)$ & 31.835 & $<0.001$ \\
\hline Sexuality & sex & $151(30.2)$ & $374(74.8)$ & 199.41 & $<0.001$ \\
\hline & Knowledge about sex & $249(49.8)$ & $443(88.6)$ & 176.58 & $<0.001$ \\
\hline & Fights at college & $58(11.6)$ & $94(18.8)$ & 10.048 & $<0.005$ \\
\hline Safety & Carries weapons to college & $10(2)$ & $16(3.2)$ & 1.420 & $>0.10$ \\
\hline & Ever involved in fights & $53(10.6)$ & $47(9.4)$ & 0.40 & $>0.50$ \\
\hline & Other's irritating nature & $31(57.4)$ & $26(55.31)$ & 14.293 & $<0.001$ \\
\hline Reasons for fights (among those who fought) & Injustice & $7(12.96)$ & $3(6.3)$ & 1.183 & $>0.10$ \\
\hline & Scolding without fault & $15(28.30)$ & $18(38.29)$ & 1.125 & $>0.10$ \\
\hline Ability to walk away from fights & & $53(10.6)$ & $47(9.4)$ & 0.40 & $>0.50$ \\
\hline Ever been injured severely & & $4(0.8)$ & $5(1)$ & 0.112 & $>0.50$ \\
\hline Feels safe at home & & $472(94.4)$ & $480(96)$ & 1.400 & $>0.10$ \\
\hline & Once in a while & 433 & 446 & 1.588 & $>0.10$ \\
\hline Depression & At times & 45 & 39 & 0.467 & $>0.10$ \\
\hline & All the time & 22 & 15 & 1.374 & $>0.10$ \\
\hline Suicidal tendency & Thought of hurting oneself & $6(1.2)$ & $13(2.6)$ & 2.6279 & $>0.10$ \\
\hline & Table 1. Attit & ds Socia & & & \\
\hline
\end{tabular}




\section{RESULTS}

Absolute numbers and percentage (\%) were used to express the proportion of cases belonging to specific group of parameters or a particular problem was expressed in absolute numbers and percentage (\%).

1. Percentage $=$ Proportion X 100 .

2. Proportion $=$ Number of cases. Student' $\mathbf{s}$ ' $\mathrm{t}$ ' test is used to compare the attitude of adolescents from rural and urban population.
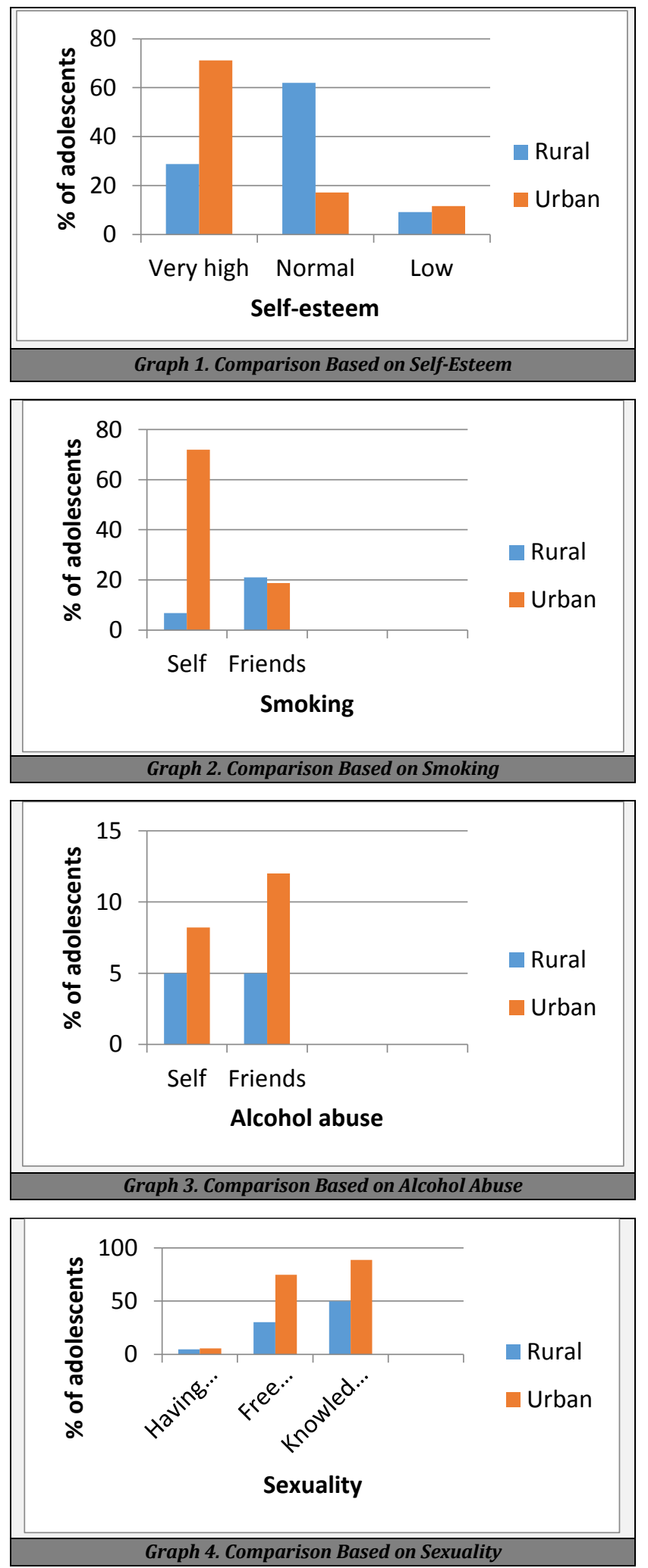

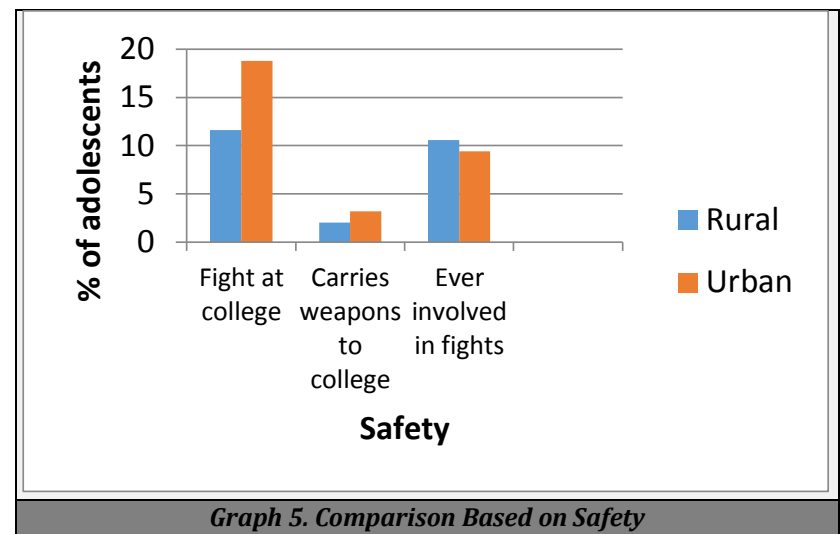

\section{DISCUSSION}

The word 'adolescere', in Latin means 'to grow, to mature' Sigmond Freaud (1856 - 1939) defined adolescence as recapitulation of childhood oedipal complex. Erick H. Erikson (1902 - 1994) defined adolescent stage as the struggle between identity and role confusion. The changes that occur in adolescence are; time of turmoil and can cause distress to both the adolescent and those who have contact with him. The task for each adolescent is to leave behind his childhood dependency on his parents and to begin to function more as an independent person. He must be able to risk parental disapproval without feeling that he must give into parental demands. This may be in the area of sexuality, friendships or work. The problems of adolescents are numerous because of the following five qualities that distinguish adolescents from adults.

1. Adolescents tend to show mood swings with a rapid fluctuation of object choice.

2. Adolescents have a need for immediate gratification.

3. An adolescent is particularly not aware of the possible sequelae of his or her action. He / she misunderstands other's behaviours and emotions.

4. There is a lack of self-criticism in adolescence.

5. An adolescent thinks his world is different from that of an adult and fancies it. ${ }^{4}$

Adolescents feel that they are unduly restricted and unfairly treated by their parents. Parents blame the adolescents for mis / non-communication and for being hostile. ${ }^{5}$

\section{Developmental Tasks of Adolscence 6}

Early Adolescence

Early adolescence is characterised by adolescents starting to realise the differences from their parents. They develop a strong peer identification and try to explore everything (violence / smoking etc).

\section{Mid Adolescence}

During mid-adolescence, emotional separation from the parents gets established and peer group identification is intensified. Risk taking behaviour (drug addiction / alcoholism / smoking / sexual exploration) is increased. They develop 
interest in peers of opposite sex. They start planning holidays and develop educational trajectories. ${ }^{7}$

\section{Late Adolescence}

During late adolescence social autonomy is established and adolescents like to stay away from parents further. They initiate intimate relationships with peers and keep the parents away from peer groups. They decide on their vocational plans and they become financially independent.

Adolescent's social attitude changes with onset of puberty. They start preferring loneliness and tend to avoid group activities. Their social attitude and behaviour become increasingly antisocial as the puberty advances. ${ }^{8}$

The accelerated urbanisation has brought about intense competition amongst today's adolescents. They feel the elder's advice as monotonous and their experiences as irrelevant to the present context. They believe in creativity and modern technology to achieve more and more. Their commitment in this regard will take them to new heights.

Adolescents are highly affected by the revolutionary changes in society that have taken place off late, and which can have a deleterious impact on adolescent's health. We witness many psychosocial changes during adolescent period. Important changes observed are development internalised and integrated sense of identity which implies staying away from family and parents and developing intimacy with peers and taking important life decisions. ${ }^{9}$

This is the period when they start involving and mingling with peers of opposite sex and gradually get attracted towards them, sometimes resulting in sexual pairing. Girls as they mature earlier, may experience sexual interest earlier than boys; sometimes culminating in sexual activity, although this depends on the culture and traditions of the societies where they live in. As such, the increased interval between sexual maturity and the incidence of premarital sexual intercourse is on the rise. ${ }^{10}$

The adolescents form a significant proportion of Indian population. While India continues to face challenges of poverty and underdevelopment, a new set of problems related to change in lifestyle and urbanisation has raised. In a society which is beset with problems of inequality on the basis of gender and caste, exploitation is common.

\section{Attitude towards Social Aspects}

\section{Self Esteem}

High self-esteem in urban adolescents was because of high socio economic, educational and occupational status of the parents. The character which he / she dislikes and wants to change. In present study, most of the adolescents were eager to change their attitude mainly to overcome laziness, anger, lying, cruelty, sleepiness etc.

\section{He / She is Best at}

$44 \%$ of urban adolescents were best at studies compared to only $24.8 \%$ of rural. In sports, drawing and helping others the rural students had an upper hand.

\section{Home Atmosphere}

Only $1.6 \%$ of rural and $2.6 \%$ of urban adolescents faced problems at home in contrast to MKC Nair et al. study (2000) ${ }^{4,5}$ in which $12 \%$ of rural and $5 \%$ urban adolescents reported problems at home.

In Case of Difficulty, He / She will Approach

Majority said they would approach their mothers. Only $23.4 \%$ of rural and $25.2 \%$ of urban adolescents approached their friends.

\section{Impression towards Parents and Siblings}

$83.2 \%$ of rural and $86 \%$ of urban adolescents felt great and $15.2 \%$ of rural and $10.8 \%$ of urban adolescents felt good about their parents and siblings and had a positive attitude.

\section{People's Expectation from Adolescents}

$84 \%$ of rural adolescents said people's expectations to be very high compared to $72.4 \%$ of urban.

\section{Comfort at Home}

Most of the adolescents were comfortable at home which is in accordance with the study done by MKC Nair et al. (1999). ${ }^{11,12}$

Reaction When Upset with Parents

Major proportion said they would cry and sleep off whenever they were upset with their parents.

\section{Recreation / Entertainment}

In our study a fairly equal number of adolescents from both the groups said they would chat with their peers.

\section{Best Friend}

Majority found their best friend in their peer group.

\section{The Person with Whom He / She Confides When in Need}

Most of them said they confide to their mothers in need of hours.

\section{Smoking}

Observed no difference between rural and urban adolescents

\section{Alcohol Intake}

The difference was significant in present study. Similar study done at Delhi by Kishore J et al. (1999) ${ }^{13}$ showed a difference of $30.9 \%$ as compared to $3.2 \%$ in present study.

\section{Drug Abuse}

None of adolescents abused drug in our present study.

\section{Sexuality}

$74.8 \%$ of urban adolescents believed in free socialisation with opposite sex as compared to only $30.2 \%$ of rural.

\section{Physical Fights}

$10.6 \%$ of rural and $9.4 \%$ of urban adolescents said they were involved in fights. The difference was $1.2 \%$ as compared to $15.5 \%$ in Kishore et al. study. ${ }^{13}$ 


\section{Depression}

$13.4 \%$ of rural and $10.8 \%$ of urban adolescents were depressed which is in accordance with the study done by $\mathrm{L}$ Dassi et al. (1996) 7 in which it was $12 \%$.

\section{Suicidal Ideation}

$1.2 \%$ of rural and $2.6 \%$ of urban adolescents were having suicidal ideation, the difference between two groups being insignificant.

\section{CONCLUSIONS}

Rural and urban adolescents differed significantly with respect to development of personality traits such as selfesteem and self-concept, tender mindedness, shrewdness, internal restraint and individual capacities. High peerpressure, curiosity to explore things and more exposure to mass-media contributed to significantly increased risk-taking behaviours in urban adolescents as compared to rural adolescents. There were no significant differences between the rural and urban adolescents with respect to home / college environment, safety at home / college, relationships with parents, siblings and friends, depression and suicidal ideations, food choice, and timing of food.

Data sharing statement provided by the authors is available with the full text of this article at jemds.com.

Financial or other competing interests: None.

Disclosure forms provided by the authors are available with the full text of this article at jemds.com.

\section{REFERENCES}

[1] Cutler EM, Bateman MD, Wollan PC, et al. Parental knowledge and attitude of Minnesota laws concerning adolescent medical care. Pediatrics 1999;103(3):582-7.
[2] Mary R, Lee T, Levene MI. Pediatrics and child health. $3^{\text {rd }}$ edn. London: Blackwell Sciences Ltd., 1999: p. 345-6.

[3] Rao RA, Thirumagal V. Drug addiction in adolescents: prevention and treatment issues. Indian Journal of Practical Pediatrics IAP 1998;6(1):27-35.

[4] World Health Organization. The health of young people-a challenge and promise. Geneva: WHO 1993.

[5] Ganga N. Understanding adolescents. Teens Journal of Teenage Care and Premarital Counselling 2002;2(10\&11):92-6.

[6] Russel V. Adolescent medicine. Chap - 34. In: Neil M, Peter H, Rosalind S, eds. Forfar and Arneil's Textbook of Pediatrics. $6^{\text {th }}$ edn. Edinburgh: Churchill Livingstone 2003: p. 1757-65.

[7] Dassi A, Khan MZ. Family and the emergence of deviant behaviour among children and adolescents. The Indian Journal of Social Work 1996;61(3):421-34.

[8] Elizabeth BH. Child development. $6^{\text {th }}$ edn. New Delhi: Tata McGraw-Hill Publications 1992: p. 247-9.

[9] Harikumar SK. Counselling for youth, CDC, Kerala. Teens Journal of Teenage Care and Premarital Counselling 2002;2(8\&9):24-7.

[10] WHO. Young people's health - a challenge for society: report of a WHO study group on young people and health for all by 2000. Technical Report Series No. 731. World Health Organization 1986.

[11] Nair MKC, Pejaver RK. Life skills for psychosocial competence. Chap - 12. In: Adolescent care 2000 and beyond. Bangalore: Prism Books Pvt Ltd., 2001: p. 130-9.

[12] Nair MKC, Pejavar RK. Adolescent perceptions. Chap - 10. In: Adolescent care 2000 and beyond. Bangalore: Prism Books Pvt Ltd., 2001: p. 108-15.

[13] Kishore J, Singh A, Grewal I, et al. Risk behaviour in an urban and a rural male adolescent population. Natl Med J India 1999;12(13):107-10. 